\title{
Quantitative Analysis of the Expression of Whey Acidic Protein (WAP) mRNA in the Prolactin-Responsive Mouse Mammary Gland Epithelial Cell Line, HC11
}

\author{
Yuji KAWAMATA, Junko ISHIJIMA, Satoshi TANAKA, Masato SASAKI"1), \\ Jumpei ENAMI ${ }^{2)}$, Hideaki TOJO and Chikashi TACHI \\ Laboratory of Applied Genetics, Department of Bio-Regulatory Systems, \\ Institute of Animal Resource Science, School of Agriculture and \\ Life Science, University of Tokyo, 1-1-1 Yayoi, Bunkyo-ku, Tokyo 113, and \\ 1)Zenyaku Kogyo Co., Ltd., 2-23-7, Oizumi-machi, \\ Nerima-ku, Tokyo 177, Japan
}

\begin{abstract}
The prolactin (PRL)-responsive cell line, HC11, derived from normal mammary epithelial cell line COMMA-1D, expressed the long form of prolactin receptor (L-PRLR) mRNA, though the level was considerably lower than that in the mammary gland of the normal lactating mouse. HC11 cells expressed whey acidic protein (WAP) mRNA, when they were cultured to confluence and 'in vitro lactogenesis' was induced by the addition of PRL, insulin and dexamethasone. The levels of PRL-induced WAP expression, as measured by reverse transcriptase mediated polymerase chain reaction (RT-PCR), increased in a dose-dependent manner, as PRL concentrations were raised from $0.05 \mu \mathrm{g} / \mathrm{ml}$ to $50 \mu \mathrm{g} / \mathrm{ml}$. Treatment of HC11 cells with human growth hormone (hGH) caused increase in levels of WAP mRNA. In contrast to PRL, hGH showed its maximum effect at $0.5 \mu \mathrm{g} /$ $\mathrm{ml}$. Beyond this concentration, the effect of hGH was greatly reduced. These results suggest that hGH has a narrow optimal concentration range with regard to the stimulation of WAP expression in $\mathrm{HC} 11$ cells.
\end{abstract}

Key words: Long form of prolactin receptor, HC11, Whey acidic protein, Mammary gland, Prolactin.

(J. Reprod. Dev. 41: 331-338, 1995)

$\mathbf{U}$ nderstanding of the molecular mechanisms underlying the tissue-specific and stage-specific expression of genes in differentiating cells will not only answer one of the most fundamental questions in biology, but also will provide us useful knowledge to solve practical problems in agriculture and medicine. In the mammary gland, the expression of genes coding for major milk protein components, e.g., caseins, lactoglobulins, $\alpha$-lactalbumin, whey acidic protein (WAP) etc., is precisely regulated in tissue-specific and stage-specific man-

Accepted for publication: September 21, 1995 Correspondence: $C$. Tachi ners [1-4]. At lactogenesis, mammary epithelial cells undergo remarkable morphological and functional changes under the influence of various peptide as well as steroid hormones [2-4]. Notably prolactin (PRL) plays a key role in the lactogenesis of mammals by stimulating the target cells, via prolactin receptors (PRLR), leading to the increased production of milk proteins [5-7].

In recent years, strong attention of researchers has been focused upon the molecular mechanisms underlying the PRL-PRLR-target protein relationship [8-12], and the major pathways of signal transduction have been clarified [13-16], although 
many fundamental problems remain yet to be solved.

The series of experiments presently described represent a part of our attempts to clarify the molecular mechanisms underlying PRL-PRLR-target gene relationships using the PRL-responsive mammary epithelial cell line, HC11, which was recloned [17] from COMMA-1D cells originally derived from a pregnant BALB/c mouse [18].

HC11 cells express $\beta$-casein mRNA $[19,20]$ and WAP mRNA [21], when the 'in vitro lactogenesis' was induced by hormones including PRL. Although $\beta$-casein synthesis in HC11 cells has been shown to respond to PRL in a dose-dependent manner [17], no report, to date, has dealt with the dose-related effects of PRL upon the WAP gene expression. In the present paper, we demonstrate that the expression of WAP gene is regulated by prolactin in a dose-dependent manner in HC11 cells.

\section{Materials and Methods}

\section{Cell culture}

The HC11 cell line used throughout the present series of experiments was kindly provided by Dr. R. K. Ball, Friedrich Miescher Institute, Switzerland. The cells were cultured in collagen-coated plastic dishes (100 mm in diameter; cat. no.25020, Corning, New York, U.S.A.) under a humidified atmosphere of $5 \% \mathrm{CO}_{2}$ in air at $37 \mathrm{C}$.

Fetal bovine serum (FBS) was purchased from Cell Culture Laboratories \& Co., Ltd., Cleveland, Ohio (lot no. 01025-01, cat. no. 10-1010-50). Heatinactivation was carried out at $56 \mathrm{C}$ for $30 \mathrm{~min}$. Powdered RPMI1640 without sodium bicarbonate (cat. no. 430-1800EB, Gibco Life Technologies, New York, N.Y.) was dissolved in quartz distilled wa- ter. Sodium bicarbonate (Wako Chemicals, Osaka, Japan) was added at a concentration of $2.0 \mathrm{~g} / 1$. During the logarithmic phase, cells were cultured in RPMI1640 medium containing 10\% (v/v) heatinactivated FBS, $5 \mu \mathrm{g} / \mathrm{ml}$ of insulin (cat. no. I-5500, Sigma Chemical Co., St. Louis, Mo.), $10 \mathrm{ng} / \mathrm{ml}$ of epidermal growth factor (EGF) (cat. no. 40001, Collaborative Biomedical Products, Bedford, Mass.), and $50 \mu \mathrm{g} / \mathrm{ml}$ of gentamycin (Wako Chemicals, Osaka, Japan). This medium has been designated the HC11-1640-G medium in our laboratory. For the induction phase of the lactogenesis, the HC11-1640-I medium (RPMI1640 added with FBS $(2 \%, \mathrm{v} / \mathrm{v})$, insulin $(5 \mu \mathrm{g} / \mathrm{ml})$ and gentamycin $(50 \mu \mathrm{g} / \mathrm{ml}))$ was used.

For passage, cells in the 'non-lactogenic' states were trypsinized in $\mathrm{Ca}^{2+}$ - and $\mathrm{Mg}^{2+}$-free Hanks' balanced salt solution containing $1 \mathrm{mM}$ of EDTA (CMFE-Hanks), suspended in 7-10 ml of HC111640-G and seeded at an approximate concentration of $1-2.5 \times 10^{5}$ cells per $100-\mathrm{mm}$ dish.

For induction of differentiation by hormones, treatment of HC11 cells with ovine PRL (31 IU/ mg; cat. no. L6520; Sigma Chemical Co., St Louis, Mo.) or hGH (2 IU/mg; cat. no. S4776; Sigma Chemical Co., St. Louis, Mo.) was commenced 2 days after confluence was reached. The cells were exposed to the hypophysial hormones for 2 days in HC11-1640-I supplemented with dexamethasone $(0.1 \mu \mathrm{M})$ (cat. no. D4902 Sigma Chemical Co., St. Louis, Mo.). The schedule for the hormonal treatment is schematically presented in Fig. 1.

\section{RNA extraction}

For RNA extraction, the acid guanidinium thiocyan-ate-phenol-chloroform (AGPC) method [22] was employed. The cells were lysed by adding 3 $\mathrm{ml}$ of solution $\mathrm{D}$ (4 M guanidine thiocyanate, 25 $\mathrm{mM}$ sodium citrate, $0.5 \%$ sodium sarkosyl, $0.1 \mathrm{M}$

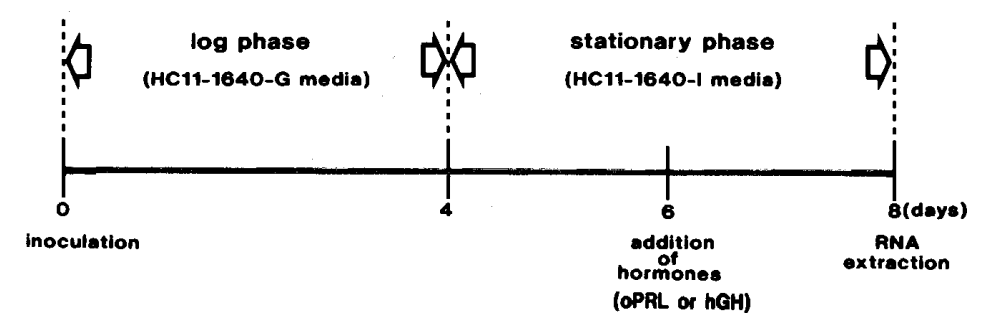

Fig. 1. Schematic illustration of the schedule for the hormonal treatment of HC11 cells. 
2-mercaptoethanol; $\mathrm{pH}$ 7.0). The solution was mixed well with $0.3 \mathrm{ml}$ of $2 \mathrm{M}$ sodium acetate buffer ( $\mathrm{pH} 4.0$ ), $3 \mathrm{ml}$ of phenol, and $0.6 \mathrm{ml}$ of chloroformisoamyl alcohol (24:1). The mixture was centrifuged at 3,000 r. p. m. for $20 \mathrm{~min}$ at $4 \mathrm{C}$. The supernatant was collected, precipitated with isopropanol and the pellet was redissolved in $0.5 \mathrm{ml}$ of solution D. The RNA preparation was treated again with phenol-chloroform, and finally precipitated with isopropanol as described above. The resultant pellet was rinsed with $75 \%$ ethanol and dissolved in a 40-60 $\mu \mathrm{l}$ of DEPC-treated water.

Reverse-transcriptase mediated polymerase-chainreaction ( $R T-P C R$ )

Total RNA $(1 \mu \mathrm{g})$ was heat-denatured at $65 \mathrm{C}$ for $3 \mathrm{~min}$, and reverse-transcribed at $37 \mathrm{C}$ for $1 \mathrm{~h}$ in $20 \mu \mathrm{l}$ of a reaction mixture containing $10 \mathrm{mM}$ Tris- $\mathrm{HCl}(\mathrm{pH} 8.3), 50 \mathrm{mM} \mathrm{KCl}, 0.001 \%$ gelatin, 5 $\mu \mathrm{M}$ random hexamers (Takara Shuzo, Kyoto, Japan), $0.5 \mathrm{mM}$ of deoxyribonucleoside triphosphates (dNTPs) (Takara Shuzo), $40 \mathrm{U}$ ribonuclease inhibitor (Takara Shuzo), and 200 U reverse transcriptase (Bethesda Research Laboratories \& Co., Bethesda, Md.). For WAP cDNA amplification, the published primer sequences were used; i.e., $5^{\prime}$ TG T A T C A T C T GC CA A A C C A A C GA G-3' (5'-primer) and 5'-GAAGGGTCTTGCTGTATAGACTTGGGCTGG-3' (3'-primer) [21]. The $5^{\prime}$-primer was in the second, and the $3^{\prime}$-primer was in the fourth exon; they are to yield a 349 bp product. The relative positions of the primers and the probe are shown in Fig. 2. For amplification, $10 \mu \mathrm{l}$ of the RT reaction products were added to a PCR reaction mixture containing $10 \mathrm{mM}$ Tris ( $\mathrm{pH} 8.3$ ), $50 \mathrm{mM} \mathrm{KCl}, 4.5 \mathrm{mM} \mathrm{MgCl} 2,0.4 \mu \mathrm{M}$ of each primer, and $1.5 \mathrm{U}$ Taq polymerase (Takara Shuzo). The reactions were carried out for 32 cycles in a PC700 programmed temperature control equipment (Astec, Fukuoka, Japan) under the following conditions: $1 \mathrm{~min}$ at $94 \mathrm{C}, 1 \mathrm{~min}$ at $60 \mathrm{C}$, and $1 \mathrm{~min}$ at $72 \mathrm{C}$. The identity of the PCR products was confirmed by Southern hybridization using the probe shown in Fig. 2.

For mouse $\beta$-actin cDNA amplification, primers (5'primer, 5'-GTGGCCGCTCTAGGCACCAA-3'; 3'primer, 5'-CTCTTTGATGTCACGCACGATTTC$\left.3^{\prime}\right)$, which yield a 539 bp product were purchased from Clontech Laboratories, Inc., California, U.S.A. [24]. The composition of the PCR mixture was the same as that used for WAP cDNA amplification, except that the concentration of $\mathrm{MgCl}_{2}$ was reduced to $1.5 \mathrm{mM}$. The reaction profile was 30 cycles of 1 min at $94 \mathrm{C}, 1 \mathrm{~min}$ at $65 \mathrm{C}$, and $1 \mathrm{~min}$ at $72 \mathrm{C}$. To amplify the cDNA coding for the intracellular domain of mouse L-PRLR (DDBJ accession number D10214), the following primers were used; i.e., $5^{\prime}$ AGCATGATGACCTGCATCTTTCCAC-3' $\left(5^{\prime}\right.$-primer) and 5'-GTCCAAGAAAGAGTCCAGTGTATCT-3' (3'-primer). They are to yield $561 \mathrm{bp}$ fragments. The reaction conditions were 33 cycles of $1 \mathrm{~min}$ at $94 \mathrm{C}, 1 \mathrm{~min}$ at $60 \mathrm{C}$, and $1 \mathrm{~min}$ at $72 \mathrm{C}$.

genomic WAP DNA

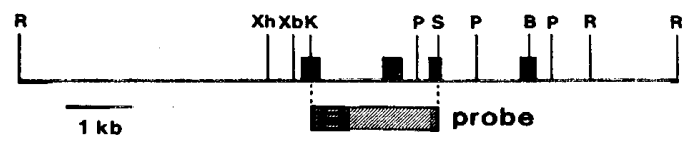

CDNA

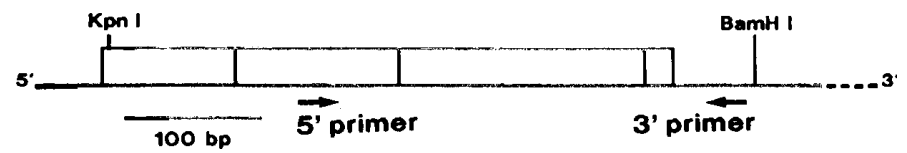

Fig. 2. Schematic illustration of the structure of mouse genomic WAP DNA [23] and cDNA [23] showing the positions of the probe and the primers. Solid boxes indicate the exons. The hatched box shows the position of the probe. E, EcoRI; B, BamHI; K, KpnI; P, PstI; S, SalI; Xb, XbaI; Xh, XhoI. Scale bar $=1 \mathrm{~kb}$. Open boxes represent the coding region. Arrows indicate the relative position of the primers. Scale bar $=100 \mathrm{bp}$. 
Quantitative analysis of the PCR products

PCR products were electrophoresed in a $1.8 \%$ SeaKem GTG agarose gels (cat. no. 50072; FMC BioProducts, Rockland, USA) in a TAE buffer, and transferred onto Hybond-N+ membranes (cat. no. RPN303B; Amersham International plc, Buckinghamshire, England). The Southern blot analysis was carried out by means of the ECL system $(\mathrm{Nu}-$ cleic Acid Direct Labelling and Detection System; cat. no. RPN3000; Amersham International plc, Buckinghamshire, England), using the probe shown in Fig. 2. Densitometric analyses of the photographic records were done by means of a personal computer-based image analysis system [25].

\section{Estimation of the cellular RNA/DNA ratios}

The extraction and the fractionation of nucleic acids were done according to Schmidt-Thannhauser-Schneider method [26]. DNA contents were determined by Burton's method [27], and RNA contents, by orcinol reaction [28].

\section{Results}

\section{HC11 Cells in culture}

In typical experiments, $2.5 \times 10^{5} \mathrm{HC} 11$ cells were seeded onto a collagen-coated dish $(100 \mathrm{~mm}$ in diameter) and grown in HC11-1640-G. In the logarithmic phase, the cells were elongated in shape and formed a monolayer sheet. After they reached confluence, many cells tended to take compact spherical shapes. A typical growth curve is presented in Fig. 3. The cellular density at the plateau phase was approximately $2-3 \times 10^{7}$ cells per dish.

Using the culture system described above, we first examined whether PRL has any effects on the total RNA content in HC11 cells. At the end of the logarithmic phase, the medium was shifted to HC11-1640-I. After 2 days, PRL together with dexamethasone (final concentration of dexamethasone, $0.1 \mu \mathrm{M}$ ) were added to the culture. The RNA/ DNA ratios of the cells, after addition of prolactin at different concentrations $(0-50 \mu \mathrm{g} / \mathrm{ml})$, stayed at almost the same levels throughout the range examined (Fig. 4), indicating that PRL may not increase the rate of overall RNA synthesis in these cells.

We then examined whether L-PRLR mRNA is expressed in the HC11 cells passaged in our labo-

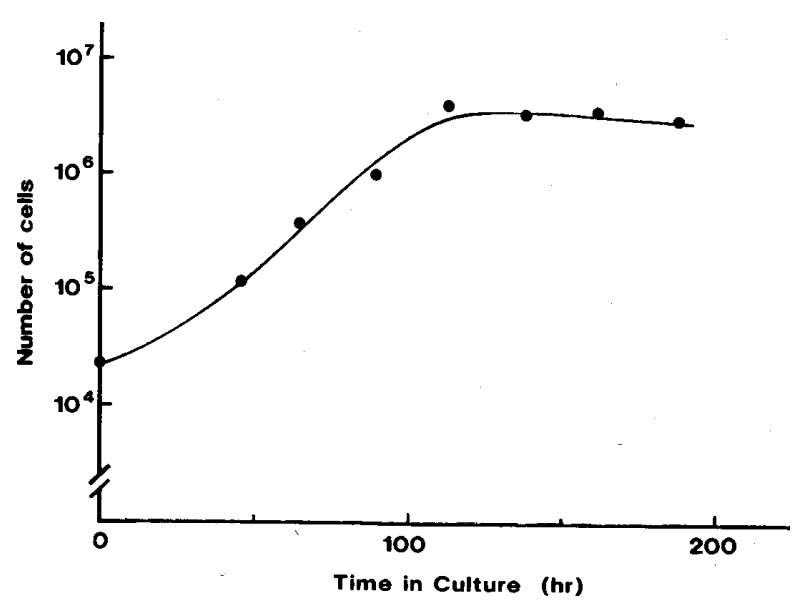

Fig. 3. A typical growth curve of HC11 cells.

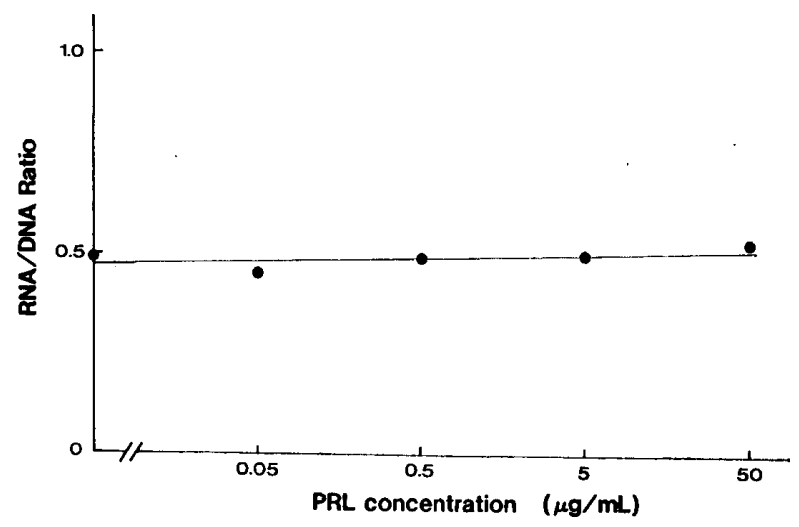

Fig. 4. Changes in RNA/DNA ratios after addition of prolactin at different concentrations. Results from one typical series of experiments are plotted.

ratory. As shown in Fig. 5, the expression of LPRLR gene in these cells was confirmed by RT-PCR in both logarithmic and stationary phases (Fig. 5).

\section{Standardization of quantitative RT-PCR}

In order to quantitatively measure the expression levels of specific mRNA, conditions for RT-PCR were investigated. The amounts of RTPCR products were quantitatively analyzed by densitometry as described in Materials and Methods, according to the number of PCR cycles (Fig. 6), and the amount of specific mRNA (Fig. 7). A good linear relationship was obtained between the logarithm of the amount of RT-PCR product and the number of reaction cycles between 27 and 39 cycles (Fig. 6). Based on this observation, 32 cy- 


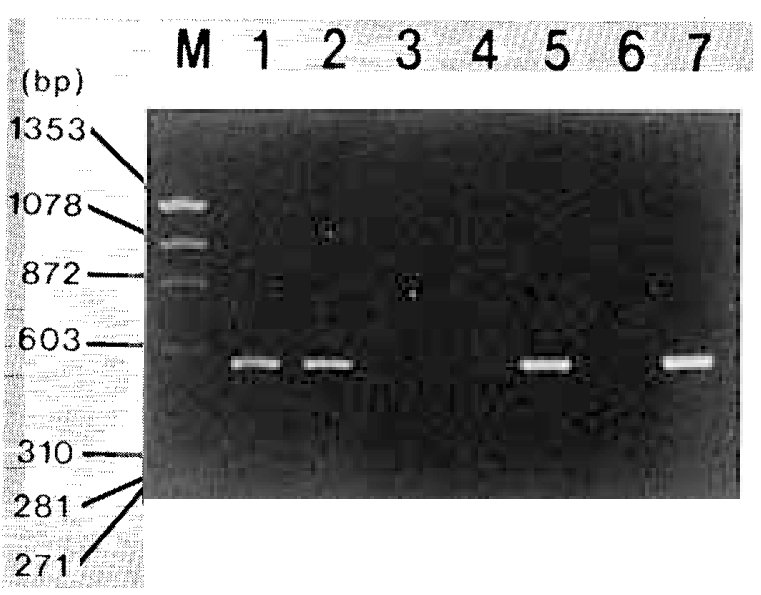

Fig. 5. Expression of the L-PRLR gene in HC11 cells. M, DNA molecular markers (HaeIII digests of øX174 DNA) ; Lane 1, HC11 in the logarithmic phase; lane 2, HC11 at the confluence; lane 3, the same as for lane 2 except reverse transcriptase was omitted from the reaction mixtures; lane 4, blank (no templates were added to the mixture); lane 5, liver from a female mouse on Day 10 of lactation; lane 6, the same for lane 5 except the amount of the charged sample was $1 / 20$ of lane 5 ; lane 7 , lactating mammary gland (Day 10 of lactation). The amounts of RNA charged for RT were $1 \mu \mathrm{g} /$ lane except in the lane $6(0.05 \mu \mathrm{g} /$ lane $)$. The arrow head indicates the position of the expected DNA size (561 bp).

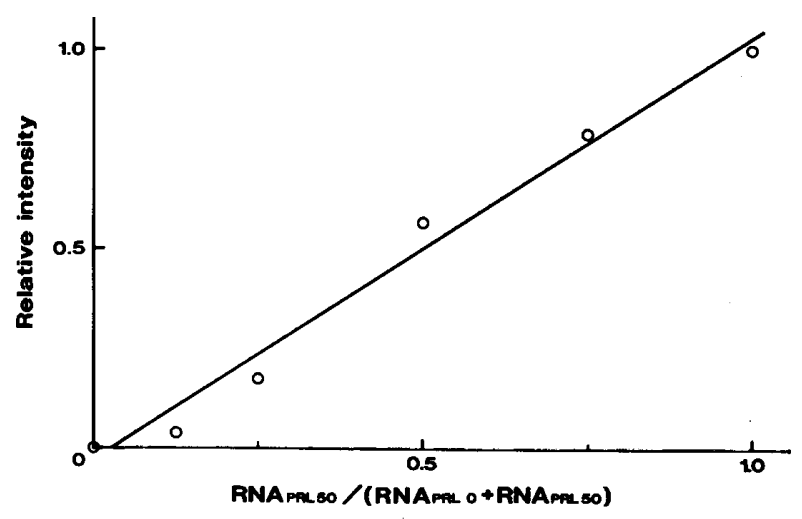

Fig. 6. Relationship between the numbers of cycles and the amounts of PCR products. The amplification was carried out using the WAP primers. The amount of RNA used was $1 \mu \mathrm{g}$ for each RT reaction.

cles of PCR was selected and used for examination of linearity with the amount of input RNA. As shown in Fig. 7, a good linear relationship was obtained between the amount of RT-PCR product and the amount of input WAP mRNA.

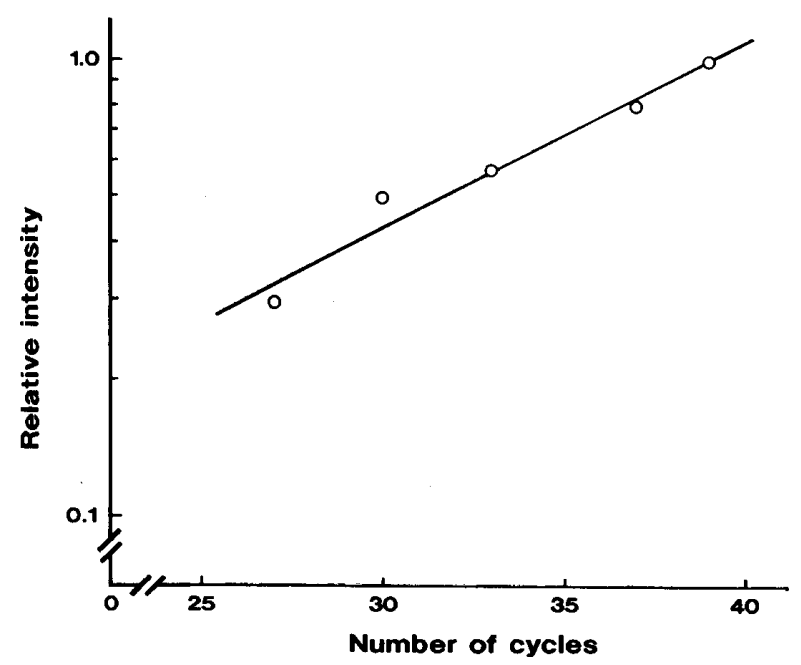

Fig. 7. Relationship between the relative WAP mRNA contents in the template RNA and the amounts of PCR product under the fixed PCR conditions. $\mathrm{RNA}_{\text {PRL } 0}$, RNA of the HC11 cells at the confluence

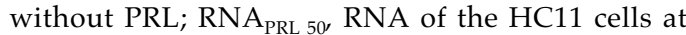
the confluence with PRL $(50 \mu \mathrm{g} / \mathrm{ml})$. Blank value (without reverse transcriptase) was subtracted from each experimental data.

\section{Induction of WAP gene expression by PRL}

Varying amounts of ovine PRL were added to the cells cultured in HC11-1640-I supplemented with dexamethasone, and the quantity of WAP mRNA in the extracted RNA was assayed by the RT-PCR as described above. The results are presented in Fig. 8. As evidently seen in the figure, the WAP mRNA levels became detectable at a PRL concentration of $0.05 \mu \mathrm{g} / \mathrm{ml}$, increased in a dosedependent manner, and nearly saturated at 50.0 $\mu \mathrm{g} / \mathrm{ml}$.

Transcripts of $\beta$-actin gene, a house-keeping gene, were used as the internal standard for RTPCR; no significant difference was noted in the expression levels among the samples (data not shown).

\section{WAP gene expression induced by $h \mathrm{GH}$}

Since hGH has been known to bind to PRLR of the mouse (mPRLR) $[9,10,29,30]$, the effect of hGH upon the WAP mRNA expression in HC11 cells was examined.

Our data demonstrated that the WAP mRNA expression was indeed inducible by hGH. The effect, however, peaked at the hGH concentration of 
$0.5 \mu \mathrm{g} / \mathrm{ml}$; at higher concentrations of hGH, levels of WAP gene expression were much reduced (Fig. 9).

\section{Discussion}

The HC11 cells passaged in our laboratory expressed L-PRLR genes as revealed by RT-PCR, confirming the earlier observation of Buck et al. [31] who employed the northern blot analysis.

When prolactin was added to HC11 cells, they responded by increasing the expression levels of

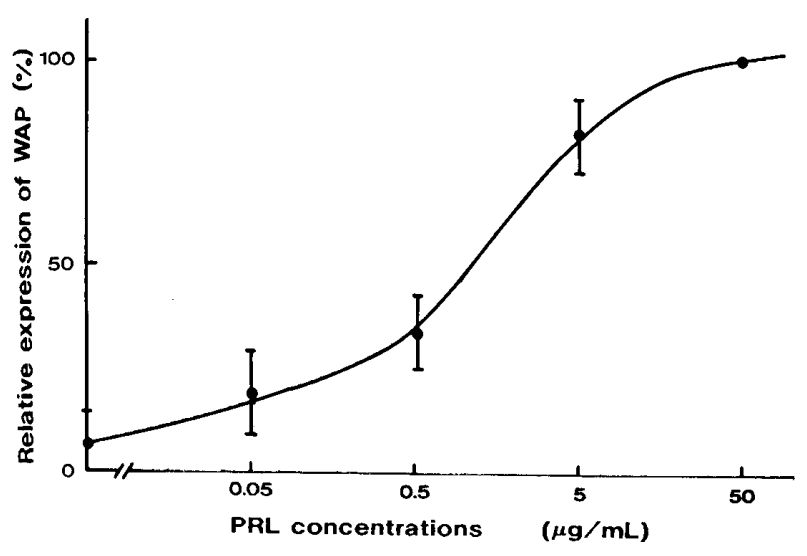

Fig. 8. Expression of WAP gene induced by PRL at different concentrations in HC11 cells. Relative expression levels were calculated as the percentage of the value at $50 \mu \mathrm{g} / \mathrm{ml}$. Mean \pm S.E.M. At least 3 independent samples were measured for each point.

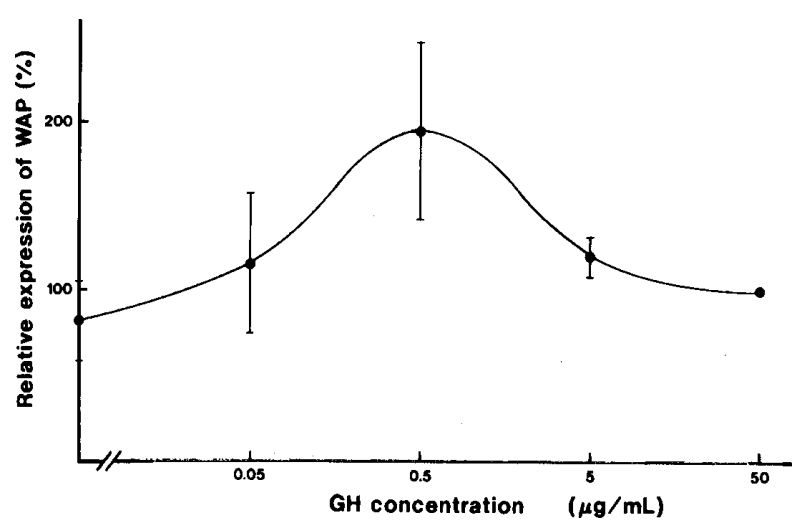

Fig. 9. Expression of WAP gene induced by hGH in HC11 cells. Relative expression levels were calculated as the percentage of the value at $50 \mu \mathrm{g} / \mathrm{ml}$. Mean \pm S.E.M. The number of experiments for each point was 3.
WAP mRNA in a dose-dependent manner. The stimulating effect of PRL upon the WAP expression became first detectable at $0.05 \mu \mathrm{g} / \mathrm{ml}$. The amount of WAP mRNA per unit amount of RNA or DNA increased linearly within the dose range of $5 \mu \mathrm{g} / \mathrm{ml}$ to $50 \mu \mathrm{g} / \mathrm{ml}$.

In the primary cultures of mouse mammary epithelial (PMME) cells, the PRL-induced WAP mRNA transcription and translation appears to be dependent upon the formation of the alveoli-like 3-dimensional spheres [32]. In HC11 cells, however, no such 3-dimensional morphological transformation of the cells are needed for the similar effects of PRL, although the expression levels of WAP genes are lower than those observed in PMME cells [21].

Ball et al. [17] reported that PRL stimulated the $\beta$-casein synthesis in a dose-dependent manner in HC11 cells within the dose range of $0.1-1.5 \mu \mathrm{g} / \mathrm{ml}$. So far no report has dealt with the dose-dependent effects of PRL upon the WAP expression. The effective dose range of PRL for stimulation of WAP expression was higher than that for casein mRNA expression, although the underlying reasons remain unclear.

Curious results were obtained with regard to the effect of hGH upon the WAP expression; hGH exhibited very narrow effective concentration ranges between $0.05 \mu \mathrm{g} / \mathrm{ml}\left(2 \times 10^{-3} \mathrm{nM}\right)$ and $5 \mu \mathrm{g} / \mathrm{ml}(2$ $\left.\times 10^{-1} \mathrm{nM}\right)$ in stimulating the WAP expression in HC11 cells.

Structural similarities of growth hormone receptors (GHR) and PRLR have been well documented $[9,10,33]$, and hGH has been known to bind to PRLR [33]. So far 2 receptor-binding sites (Site 1 and 2) have been identified on hGH [33, 34]; binding of those sites to hGH receptor (hGHR) has been considered to result in sequential dimerization of hGHR and activation of hGHR function [34-36]. At high hGH concentrations, the dimerization is inhibited owing to excessive binding of hGH to hGHR [36].

Since, activation of PRLR by hGH has been shown to proceed probably by a similar sequential dimerization mechanisms [36], the most probable explanation for the presently observed bell-shaped dose-response curve may be that high concentrations of hGH inhibit the dimerization of L-PRLR.

Indeed, Fuh et al. [37] demonstrated using the rat $\mathrm{Nb} 2$ pre- $\mathrm{T}$ lymphoma and the IL-3 dependent murine FDC-P1 myeloid leukemia cell-line trans- 
fected with DNA coding for hPRLR receptor, that dose-response relationship between the hGH concentration and the rate of cell proliferation is bell-shaped between $10^{-1} \mathrm{nM}$ and $10^{4} \mathrm{nM}$.

In HC11 cells, the effective concentration range is much narrower compared to those in $\mathrm{Nb} 2$ and FDC-P1 cells. The difference may be explained by relatively small number of PRLR expressed on the HC11 cell membrane (about $10^{2}$ PRL binding sites / cell, J. Ishijima et al., in preparation).

Another possible explanation for the bell-shaped dose-response relationship presently observed is that the heterotypic ligand, i.e., hGH, bound to PRLR might be turned over more slowly than the isotypic ligand, i.e., PRL leading to the reduced rate of renewal of PRLR and thus the decreased sensitivity of cells to the hormone.

The validity of the hypotheses, however, must be corroborated by further experiments.

\section{Acknowledgments}

Our sincere thanks are due to Professor M. Takahashi, Laboratory of Veterinary Physiology, Faculty of Agricultural Science, University of Tokyo, for his valuable discussions and support given to the present work. We thank Professor K. Kohmoto and Associate Professor S. Sakai, Laboratory of Animal Breeding, Faculty of Agricultural Science, University of Tokyo, for their support and expert advice on our work. We are grateful to Dr R. K. Ball, Friedlich Miescher Institute, Switzerland for the generous supply of HC11 cells. This work was supported in part by Grants-in-Aid from the Ministry of Education and Culture of Japan, \#04556040, \#05454111, \#05304023, and \#04304023.

\section{References}

1. Linzell JL, Peaker M. Mechanism of milk secretion. Physiol Rev 1971; 51: 564-597.

2. Banerjee, MR. Responses of the mammary gland to hormones. Int Rev Cytol 1976; 47: 1-97.

3. Topper YJ, Freeman CS. Multiple hormone interactions in the developmental biology of the mammary gland. Physiol Rev 1980; 60: 1049-1106.

4. Hobbs AA, Richards DA, Kessler DD, Rosen JM. Complex hormonal regulation of casein gene expression. J Biol Chem 1982; 257: 3598-3605.

5. Guyette WA, Matusik RJ, Rosen JM. Prolactinmediated transcriptional and post-transcriptional control of casein gene expression. Cell 1979; 17: 1013-1023.

6. Lesueur L, Edery M, Ali S, Paly J, Kelly PA, Djiane J. Comparison of long and short forms of the prolactin receptor on prolactin-induced milk protein gene transcription. Proc Natl Acad Sci USA 1991; 88: 824-828.

7. Lesueur L, Edery M, Paly J, Kelly PA, Djiane, J. Roles of extracellular and cytoplasmic domains of the prolactin receptor in signal transduction to milk protein genes. Mol Endocrinol 1993; 7: 11781184.

8. Kelly PA, Djiane J, Katoh M, Ferland LH, Houdebine LM, Teyssot B, Dusanter-Fourt I. The interaction of prolactin with its receptors in target tissues and its mechanism of action. Rec Prog Horm Res 1984; 40: 379-439.

9. Kelly PA, Djiane J, Postel-Vinay MC, Edery M. The prolactin/growth hormone receptor family.
Endocrine Reviews 1991; 12: 235-251.

10. Kelly PA, Ali S, Rozakis M, Goujon L, Nagano M, Pellegrini I, Gould J, Djiane J, Edery M, Finidori J, Postel-Vinay MC. The growth hormone/prolactin receptor family. Recent Prog Horm Res 1993; 48: 123-164.

11. Bazan JF. Structural design and molecular evolution of a cytokine receptor superfamily. Proc Natl Acad Sci USA 1990; 87: 6934-6938.

12. Ormandy CJ, Sutherland RL. Mechanisms of prolactin receptor regulation in mammary gland. $\mathrm{Mol}$ Cell Endocrinol 1993; 91: C1-C6.

13. Rui H, Djiane JY, Evans GA, Kelly PA, Farrar WL. Prolactin receptor triggering: evidence for rapid tyrosine kinase activation. J Biol Chem 1992; 267: 24076-24081.

14. Dusanter-Fourt I, Muller O, Ziemiecki A, Mayeux P, Drucker B, Djiane J, Wilks A, Harpur AG, Fischer S, Gisselbrecht S. Identification of JAK protein tyrosine kinases as signaling molecules for prolactin. Functional analysis of prolactin receptor and prolactin-erythropoietin receptor chimera expressed in lymphoid cells. EMBO J 1994; 13: 2583-2591.

15. Gouilleux F, Wakao H, Mundt Maren, Groner B. Prolactin induces phosphorylation of Tyr694 of stat5 (MGF), a prerequisite for DNA binding and induction of transcription. EMBO J 1994; 13: 43614369.

16. Clevenger $\mathbf{C V}$, Medaglia $\mathbf{M}$. The protein tyrosine kinase p59fyn is associated with prolactin (PRL) 
receptor and is activated by PRL stimulation of Tlymphocytes. Mol Endocrinol 1994; 8: 674-681.

17. Ball RK, Friis RR, Schönenberger CA, Doppler $\mathbf{W}$, Groner B. Prolactin regulation of $\beta$-casein gene expression and of a cytosolic $120-k d$ protein in a cloned mouse mammary epithelial cell line. EMBO J 1988; 7: 2089-2095.

18. Danielson KG, Oborn CJ, Durban EM, Butel JS, Medina D. Epithelial mouse mammary cell line exhibiting normal morphogenesis in vivo and functional differentiation in vitro. Proc Natl Acad Sci USA 1984; 81: 3756-3760.

19. Doppler W, Groner B, Ball RK. Prolactin and glucocorticoid hormones synergistically induce expression of transfected rat $\beta$-casein gene promoter constructs in a mammary epithelial cell line. Proc Natl Acad Sci USA 1989; 86: 104-108.

20. Doppler W, Höck W, Hofer P, Groner B, Ball RK. Prolactin and glucocorticoid hormones control transcription of the $\beta$-casein gene by kinetically distinct mechanisms. Mol Endocrinol 1990; 4: 912919.

21. Doppler W, Villunger A, Jennewein P, Brduscha K, Groner B, Ball RK. Lactogenic hormone and cell type-specific control of the whey acidic protein gene promoter in transfected mouse cells. Mol Endocrinol 1991; 5: 1624-1632.

22. Chomczynski P, Sacchi N. Single-step method of RNA isolation by acid guanidinium thiocyanatephenol-chloroform extraction. Analyt Biochem 1987; 162: 156-159.

23. Campbell SM, Rosen JM, Henninghausen LG, Strech-Jurk U, Sippel AE. Comparison of the whey acidic protein genes of the rat and mouse. Nucleic Acids Res 1984; 12: 8685-8697.

24. Alonso S, Minty A, Bourlet Y, Buckingham M. Comparison of three actin-coding sequences in the mouse; evolutionary relationships between the actin genes of warm-blooded vertebrates. J Mol Evol 1986; 23: 11-22.

25. Tachi C. Quantitative evaluation of coat-color patterns in artificially produced chimeras of the mouse by means of a microcomputer-based videoimage analysis. Dev Genet 1988; 9: 121-154.

26. Schneider WC. A comparison of methods for the estimation of nucleic acids. J Biol Chem 1946; 164: 747-751.

27. Burton K. A study of the conditions and mechanisms of the diphenylamine reaction for the colorimetric estimation of deoxyribonucleic acid. Biochem J 1956; 62: 315-323.

28. Brown AH. Determination of pentose in the presence of large quantities of glucose. Arch Biochem 1946; 11: 269-278.

29. Cunningham BC, Bass S, Fuh G, Wells JA. Zinc mediation of the binding of human growth hormone to the human prolactin receptor. Science 1990; 250: 1709-1712.

30. Sakai S. Effect of hormones on dissociation of prolactin from the rabbit mammary gland prolactin receptor. Biochem J 1991; 279: 461-465.

31. Buck K, Vanek M, Groner B, Ball RK. Multiple forms of prolactin receptor messenger ribonucleic acid are specifically expressed and regulated in murine tissues and the mammary cell line HC11. Endocrinology 1992; 130: 1108-1114.

32. Chen L-H, Bissell MJ. A novel regulatory mechanism for whey acidic protein gene expression. Cell Regulation 1989; 1: 45-54.

33. Wells JA, Cunningham BC, Fuh G, Lowman HB, Bass SH, Mulkerrin MG, Ultsch M, de Vos AM. The molecular basis for growth hormone-receptor interactions. Rec Progr Horm Res 1993; 48: 253-275.

34. Cunningham BC, Ultsch $M$, De Vos AM, Mulkerrin MG, Clauser KR, Wells JA. Dimerization of the extracellular domain of the human growth hormone receptor by a singl hormone molecule. Science 1991; 254: 821-825.

35. De Vos AM, Ultsch M, Kossiakoff AA. Human growth hormone and extracellular domain of its receptor: crystal structure of the complex. Science 1992; 255: 306-312.

36. Fuh G, Cunningham BC, Fukunaga $R$, Nagata $S$, Goeddel DV, Wells JA. Rational design of potent antagonists to the human growth hormone receptor. Science 1992; 256: 1677-1680.

37. Fuh G, Colosi P, Wood WI, Wells JA. Mechanism-based design of prolactin receptor antagonists. J Biol Chem 1993; 268: 5376-5381. 